\title{
CAN VASCULAR SHUNTING BE INDUCED IN THE KIDNEY BY VASOACTIVE DRUGS? ${ }^{1}$
}

\author{
By FRANÇOIS C. REUBI 2 AND HENRY A. SCHROEDER \\ (From the Department of Internal Medicine and the Oscar Johnson Institute, Washington \\ University School of Medicine, and Barnes Hospital, St. Louis, Missouri)
}

(Received for publication July 15,1948 )

Modern concepts of renal physiology are based on the assumption that, at least in normal subjects without impotent or aglomerular tubules, nearly all the blood goes first through the glomeruli before reaching the peritubular capillaries (1). Therefore, blood supplying the tubular system is thought to come entirely from the efferent arterioles. Anatomists have described almost every kind of anastomosis, however, which could shunt various parts of the functioning parenchyma (2). Except by Spanner (3), little consideration has been given to their possible significance in the normal kidney (4-6). Likewise, very little is known of the role of renal lymphatic vessels in the function of the kidneys $(7,8)$.

The recent work of Trueta, et al. (9) aroused general interest in this subject, because for the first time $^{3}$ an attempt was made to demonstrate the importance of renal vascular channels which bypass the cortex. Although these authors offer only morphological evidence and employ rather vigorous methods (crushing a limb, very large doses of epinephrine, etc.), they were able to show under these conditions a shift between cortical and medullary blood flow in the rabbit. Therefore, it seemed rewarding to investigate whether a similar phenomenon occurs in human subjects and dogs under normal or pathological circumstances, and whether, as Trueta indicated, this is related to the presence of arterial hypertension. The experiments here reported were made in order to detect, if possible, any changes in the relative blood supply of the different parts of the nephron after administration of certain drugs in pharmocologically active

1 Aided by a grant from the National Institute of Health, U. S. Public Health Service.

2 Fellow of Swiss Foundation for Medical and Biological Research.

3 Actually, several years previously, Fuchs and Popper (10) dealt with the problem of the "medullary" circulation, but their evidence, based upon the separation of India ink during diuresis, was not too convincing. doses. It was believed that the opening or closing of anastomotic channels between arteries and veins would be reflected by relative changes in the renal extraction of p-amino hippurate and/or mannitol, the utilization of oxygen, or both.

\section{METHODS}

Catheterization of the right renal vein was performed in 14 patients using the technique described by other authors $(11,12)$. Eight suffered from arterial hypertension and six did not. Catheters Nos. F-8, -9 , or -10 were used. In four of the earlier experiments a single intravenous injection of sodium para-amino hippurate (PAH) and mannitol solutions was given as soon as the position of the catheter had been checked by roentgenograms. The concentration of the solutions was chosen so as to provide acceptable plasma levels during one hour or longer. In later experiments, a continuous infusion of $\mathrm{PAH}$ and mannitol was used instead of the single injection in order to provide relatively constant levels of these substances in the blood. After one, two or three simultaneous samples from the femoral artery or antecubital vein and from the right renal vein had been drawn, epinephrine or histamine was given subcutaneously, and two or three more simultaneous blood samples collected three to 45 minutes later. In one case pentothal-sodium in anesthetic dose was injected intravenously. In all experiments $\mathrm{PAH}$ and mannitol were determined in renal and peripheral blood. In six the oxygen content and in four the oxygen capacity and the hematocrit were also measured. All blood samples were centrifuged as soon as possible in order to avoid diffusion of $\mathrm{PAH}$ from red blood cells. PAH and mannitol were measured by the method of Goldring and Chasis (13) modified only as regards the technique for estimating the plasma and urine mannitol "blank" (14). The oxygen content and capacity were determined by the method of Van Slyke and Neill (15). Hematocrits were read in Wintrobe tubes. The blood pressure was measured by the auscultatory method.

In 15 dogs blood from the renal vein and from the renal artery and/or femoral artery was drawn slowly and more or less simultaneously after the vessels had been exposed under nembutal anesthesia. For technical reasons, only partial experiments could usually be performed due to the large amounts of blood necessary for complete analyses. In some dogs the arterio-venous oxygen difference and the hematocrit, and in others, the 
TABLE I

Changes in arterio-renal venous differences after intravenous injection of epinephrine in dogs

\begin{tabular}{|c|c|c|c|c|c|c|c|c|c|}
\hline Dog No. & Dose & $\begin{array}{c}\text { Time after } \\
\text { injection }\end{array}$ & $\begin{array}{c}\text { Oxygen } \\
\text { content } \\
\text { FA-RV }\end{array}$ & $\begin{array}{c}\begin{array}{c}\text { Hemo- } \\
\text { concentration } \\
\mathbf{R V}-\mathbf{F A}\end{array} \\
\mathbf{R V}\end{array}$ & $\begin{array}{c}\begin{array}{c}\text { Hemo- } \\
\text { concentration } \\
\mathbf{R V}-\mathbf{R A}\end{array} \\
\mathbf{R V}\end{array}$ & $\begin{array}{l}\text { Oxygen } \\
\text { capacity } \\
R A-R V\end{array}$ & $\begin{array}{c}\text { Plasma } \\
\text { proteins } \\
\text { RV }\end{array}$ & $\underset{\text { extraction }}{\text { PAH† }}$ & $\underset{\text { clearance }}{\text { PAH }}$ \\
\hline 19 & $\begin{array}{r}\text { mgm. } \\
0.1\end{array}$ & $\begin{array}{c}\min . \\
0 \\
5 \\
16.5\end{array}$ & $\begin{array}{l}\text { vol. } \% \\
3.20 \\
2.00 \\
4.80\end{array}$ & $\%$ & $\%$ & vol. \% & gm. \% & $\%$ & cc./min. \\
\hline 20 & 0.1 & $\begin{array}{l}0 \\
2 \\
8\end{array}$ & $\begin{array}{l}3.70 \\
1.20 \\
2.00\end{array}$ & & & & , & & \\
\hline 22 & 0.1 & $\begin{array}{r}0 \\
3 \\
10\end{array}$ & $\begin{array}{l}1.95 \\
1.40 \\
2.55\end{array}$ & & & & - & & \\
\hline 29 & 0.1 & $\begin{array}{r}0 \\
8 \\
20\end{array}$ & $\begin{array}{l}2.45 \\
1.60 \\
2.70\end{array}$ & & & & & $\begin{array}{l}85.0 \\
29.0\end{array}$ & $\begin{array}{l}90.0 \\
61.2 \\
10.8\end{array}$ \\
\hline 102 & 0.1 & $\begin{array}{r}0 \\
6 \\
15\end{array}$ & $\begin{array}{l}1.50 \\
1.85 \\
2.20\end{array}$ & & & & & $\begin{array}{l}70.0 \\
85.0 \\
82.5\end{array}$ & $\begin{array}{l}84.8 \\
84.5 \\
51.2\end{array}$ \\
\hline 105 & 0.1 & $\begin{array}{r}0 \\
7 \\
32\end{array}$ & $\begin{array}{l}1.80 \\
2.10\end{array}$ & $\begin{array}{r}11.1 \\
7.5\end{array}$ & & & & $\begin{array}{l}83.0 \\
76.7 \\
61.5\end{array}$ & \\
\hline 106 & 0.2 & $\begin{array}{r}0 \\
3 \\
12\end{array}$ & $\begin{array}{l}2.40 \\
1.85 \\
2.95\end{array}$ & $\begin{array}{r}-0.1 \\
16.3 \\
-2.7\end{array}$ & & $4.9^{*}$ & $\begin{array}{l}7.08 \\
7.50\end{array}$ & & \\
\hline 110 & 0.2 & $\begin{array}{l}0 \\
2\end{array}$ & & & $\begin{array}{l}4.8 \\
9.0\end{array}$ & -1.1 & & & \\
\hline 112 & 0.15 & $\begin{array}{l}0 \\
3.5\end{array}$ & $\begin{array}{l}1.30 \\
1.90\end{array}$ & $\begin{array}{l}1.8 \\
0\end{array}$ & 5.0 & & & & \\
\hline 116 & $\begin{array}{r}0.2 \\
5008\end{array}$ & $\begin{array}{l}0 \\
2.5 \\
10\end{array}$ & & & $\begin{array}{r}3.3 \\
13.1 \\
1.8\end{array}$ & $\begin{array}{l}-0.5 \\
-3.1\end{array}$ & & - & \\
\hline 117 & $\begin{array}{r}0.2 \\
500 \S\end{array}$ & $\begin{array}{r}0 \\
3 \\
10\end{array}$ & & & $\begin{array}{l}2.5 \\
4.0 \\
1.0\end{array}$ & & & & \\
\hline 205 & 0.25 & $\begin{array}{l}0 \\
4\end{array}$ & & & $\begin{array}{r}1.6 \\
10.8\end{array}$ & & & & \\
\hline 217 & 0.2 & $\begin{array}{r}0 \\
4 \\
28\end{array}$ & & $\begin{array}{l}0.1 \\
5.0 \\
5.8\end{array}$ & & & & $\begin{array}{l}68.5 \\
48.0 \\
65.0\end{array}$ & \\
\hline 221 & 0.1 & $\begin{array}{r}0 \\
5 \\
28\end{array}$ & & $\begin{array}{l}-8.8 \\
-2.2 \\
-3.6\end{array}$ & & & & $\begin{array}{l}57.0 \\
66.5 \\
64.0\end{array}$ & \\
\hline 231 & 0.2 & $\begin{array}{l}0 \\
3\end{array}$ & & $\begin{array}{l}6.8 \\
3.9\end{array}$ & $\begin{array}{l}6.75 \\
7.95\end{array}$ & & $\begin{array}{l}4.67 \\
5.03\end{array}$ & & \\
\hline
\end{tabular}

Note: FA indicates sample taken from femoral artery, RA from renal artery, and RV from renal vein.

FA-RV.

$\dagger \frac{\mathrm{FA}-\mathrm{RV}}{\mathrm{FA}}$.

$\$ 15$-minute periods.

Caffeine. 
TABLE II

Oxygen content, hematocrit, and corrected oxygen content in dog experiment No. 106

\begin{tabular}{|c|c|c|c|c|c|c|c|c|c|}
\hline \multirow{2}{*}{ Condition } & \multicolumn{3}{|c|}{$\mathrm{O}_{2}$ Content } & \multicolumn{3}{|c|}{ Hematocrit } & \multicolumn{3}{|c|}{ Corrected $\mathrm{O}_{2}$ content $*$} \\
\hline & $\begin{array}{c}\text { Femoral } \\
\text { artery }\end{array}$ & $\begin{array}{c}\text { Renal } \\
\text { vein }\end{array}$ & $\begin{array}{c}\mathrm{A}-\mathrm{V} \\
\text { diff. }\end{array}$ & $\begin{array}{c}\text { Femoral } \\
\text { artery }\end{array}$ & $\begin{array}{c}\text { Renal } \\
\text { vein }\end{array}$ & $\begin{array}{l}\text { Hemo- } \\
\text { conc. }\end{array}$ & $\begin{array}{c}\text { Femoral } \\
\text { artery }\end{array}$ & $\underset{\text { vein }}{\text { Renal }}$ & $\begin{array}{l}\text { A-V } \\
\text { diff. }\end{array}$ \\
\hline $\begin{array}{l}\text { Control } \\
3 \text { minutes after epinephrine } 0.2 \mathrm{mgm} \text {. } \\
12 \text { minutes after epinephrine }\end{array}$ & $\begin{array}{l}\text { vol. \% } \\
18.80 \\
20.00 \\
18.15\end{array}$ & $\begin{array}{l}\text { vol. \% } \\
16.40 \\
18.15 \\
15.20\end{array}$ & $\begin{array}{c}\text { vol. \% } \\
2.40 \\
1.85 \\
2.95\end{array}$ & $\begin{array}{c}\% \\
54.75 \\
57.10 \\
53.90\end{array}$ & $\begin{array}{c}\% \\
54.10 \\
68.20 \\
52.50\end{array}$ & 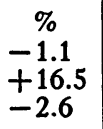 & $\begin{array}{l}\text { vol. \% } \\
18.80 \\
19.20 \\
18.40\end{array}$ & $\begin{array}{l}\text { vol. \% } \\
16.60 \\
14.60 \\
15.80\end{array}$ & $\begin{array}{c}\text { vol. \% } \\
2.20 \\
4.70 \\
2.60\end{array}$ \\
\hline
\end{tabular}

* Corrected to a constant hematocrit of 54.75 .

PAH extraction, ${ }^{4}$ were determined before and after the intravenous injection of epinephrine (50 to 200 gamma) using the methods described above.

\section{RESULTS}

a. Experiments in dogs (Tables $I, I I)$. After epinephrine was injected the difference between the oxygen content in femoral arterial and renal 4 The "extraction" is defined by the expression $\frac{P-R}{P}$, where $P$ is the concentration of the substance in the peripheral and $R$ in the renal venous plasma. venous blood was lower in five dogs (Nos. 19, $20,22,29$, and 106), and higher in three (Nos. 102, 105 and 112). The reaction to the drug was minimal in the latter (Table I). Renal arterial hematocrit values were consistently lower than venous, and the usual rise occurring after epinephrine was less marked than in renal venous blood. Femoral arterial hematocrit values were not consistent, being sometimes higher and sometimes lower than those from renal arterial blood. Epinephrine produced less hemoconcentration in fem-

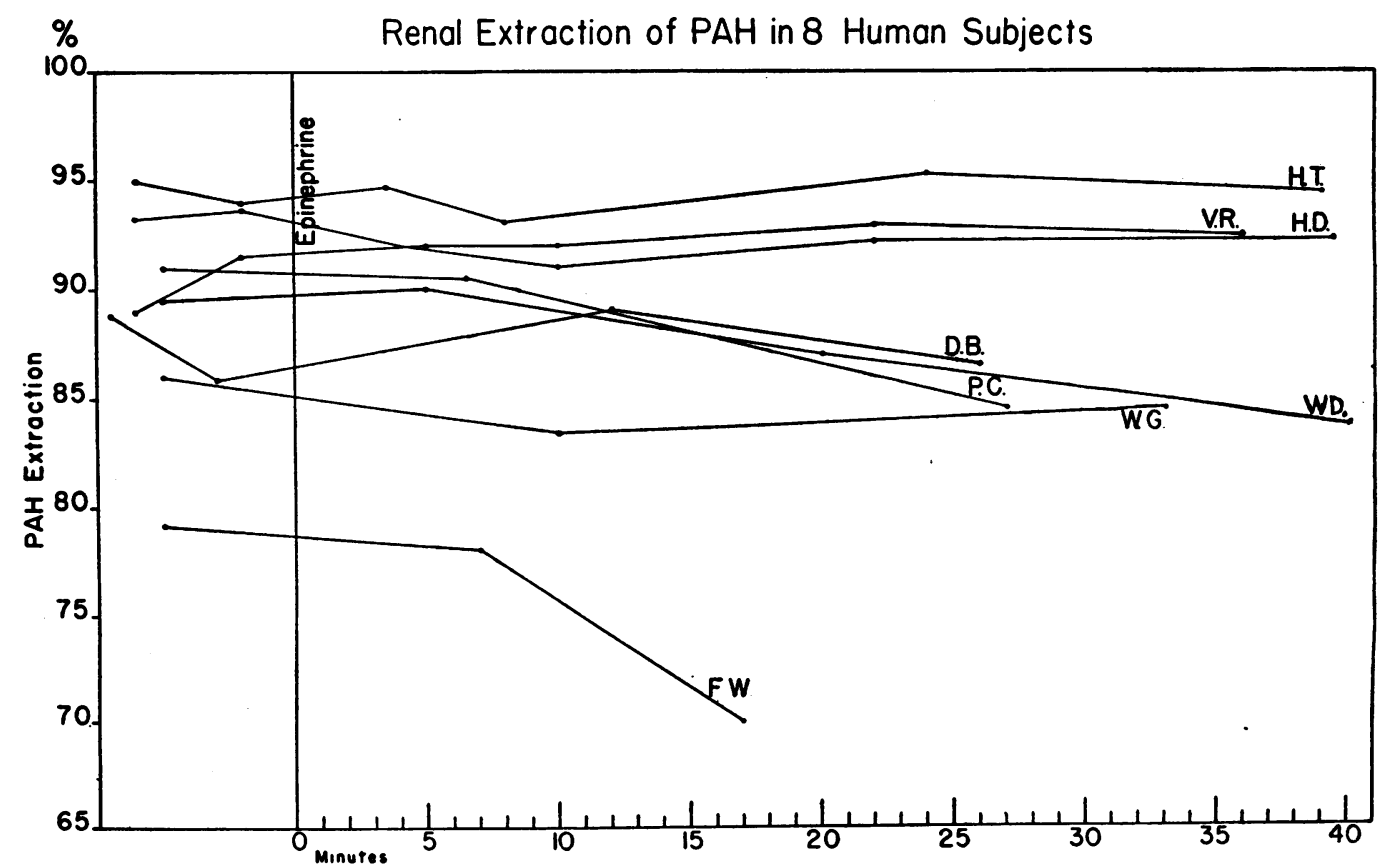

Fig. 1. Variations in the Extraction of Para-amino Hippurate by the Right Kidney after Epinephrine Was Injected Subcutaneously

The control values to the left of the vertical line were taken at least ten minutes apart, and after sufficient time had elapsed to allow the blood levels to come to equilibrium. The vertical line indicates the time of injection of epinephrine. Except for three cases, there is no significant change in the extraction of PAH (see Table III). Note that the reduction occurs only in the last determination. Patients F. W. and W. D. suffered from arterial hypertension, as did D. B. and V. R. 


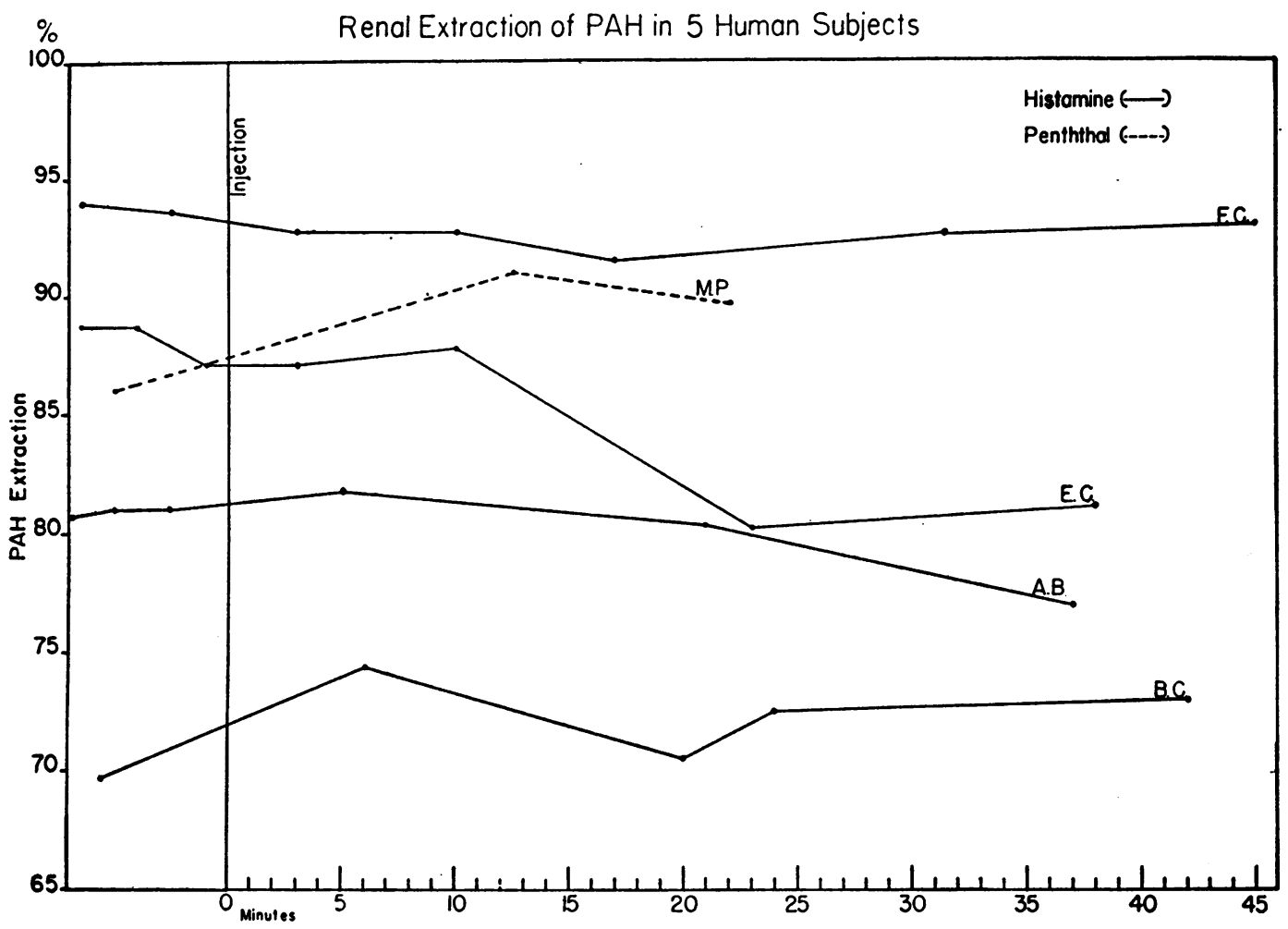

Fig. 2. Variations in the Right Renal Extraction of PaH after the Subcutaneous Injection of Histamine (- - ) and the Induction of Pentothal Anaesthesia (-- -)

All patients were hypertensive but F. C. The vertical line indicates the time of injection. Note that a significant decrease occurred only in one case (E. C.), and this 23 minutes after injection.

oral arterial blood than in that from the renal vein, except in one dog (No. 231).

Changes in the oxygen capacity paralleled the hematocrit values, and the same is roughly true with regard to the plasma proteins, indicating that actual hemoconcentration occurred. Caffeine in two experiments appeared to lessen the arteriovenous hematocrit difference. The extraction of $\mathrm{PAH}$ by one kidney was influenced by intravenous epinephrine in four of five dogs, but the direction of the change was inconsistent (Table I). In one (No. 105) it decreased progressively, in one (No. 217) temporarily, and in two it rose. One experiment indicated a pronounced fall (No. 29) but the blood sample may have become contaminated with ureteral urine.

b. Experiments in human subjects (Table III). Fourteen successful experiments were completed. Renal arterio-venous differences in oxygen content were determined in six patients. After pentothal anesthesia was given in one (M. P.) the difference was slightly increased. When epinephrine was injected it became decreased in two (W. G. and $F$. W.), but renal venous blood became more concentrated as evidenced by plasma protein levels. In two other subjects (P. C. and W. D.) the arterio-venous oxygen difference was increased. It was probably unchanged in patient $\mathrm{D}$. B., although the second arterial determination of oxygen was not entirely reliable, a small clot having been found in the syringe. Hematocrit values, determined in four cases, were increased in two by epinephrine and in one (W. D.), this was greater in renal venous than in femoral blood. They were unchanged during pentothal anesthesia in one, and slightly increased in one after histamine was injected.

The renal extraction of PAH became decreased 16 to 40 minutes after epinephrine was injected in three subjects. This decrease ranged from 91.0 to 84.5 per cent in subject P. C., from 79.7 to 69.6 in F. W., and from 89.5 to 83.7 in W. D. (Figure 1). No significant changes were observed in six patients. After histamine was given, changes occurred in two (E. C. and A. B.), where the ex- 
traction fell from 87.1 to 80.2 and from 80.7 to 77.0 respectively (Figure 2 ).

The mannitol extraction usually increased shortly after epinephrine was injected, suggesting that efferent arteriolar constriction occurred, returning to its previous level later (except in case F. W. where it was definitely lower in the last period). After histamine was given, it increased in three cases, and markedly decreased in one ( $E$. C.). Variations in the one experiment during which pentothal anesthesia was induced were not consistent.

In some of these patients urine was collected during the renal venous catheterization, and the urinary excretion of mannitol and $\mathrm{PAH}$ was compared with their renal extraction. A discrepancy between the plasma flows calculated from $C_{M} / E_{M}$ and $C_{P A B} / E_{P A B}$ was found (16). This discrepancy cannot be explained by the presence of arteriovenous shunts, as the extraction percentages of these materials were not unduly altered. These results will be reported elsewhere (17).

\section{DISCUSSION}

It is conceivable that shunts of several types exist in the kidney. It could reasonably be expected that our experiments would be capable of demonstrating at least three of them, if they were physiologically important and responded to ordinary doses of vasoactive drugs, namely:

1. Direct arterio-venous anastomoses between relatively large vessels (arcuate or interlobular), arteriola rectae, "juxta-medullary by-passes" (9, 18), which short-circuit both glomeruli and tubules. Opening of these shunts would decrease $\mathrm{PAH}$ and mannitol extractions and renal arteriovenous oxygen differences. ${ }^{5}$ This was not found to be the case.

${ }^{5}$ It is possible that "juxta-medullary by-passes" resulting from blood flowing through nephrons in this region, produce about the same effect as direct arteriovenous shunts. It is not likely that glomeruli, which have efferent arterioles as large as afferent (9), perform much filtration, and therefore little mannitol would be filtered. Even if the tubules corresponding to these glomeruli are functioning, relatively small amounts of PAH will be extracted from the blood by the tubular cells, unless there is an adequate intratubular flow of urine. Moreover, the proportion of juxta-medullary nephrons to cortical ones is probably not greater than 10 per cent (18). Therefore, if these nephrons should become
2. Vessels supplying the tubules by-passing the glomeruli. Opening of these would decrease the mannitol extraction alone, PAH and oxygen differences remaining unchanged. The same effect would be produced by the presence of "aglomerular tubules" (1). Changes in the mannitol extraction, however, were not consistent.

3. Direct communications between efferent glomerular arterioles and renal veins by-passing the peritubular capillaries. Opening of such anastomoses would decrease the PAH extraction and decrease slightly the oxygen differences, mannitol extraction being unchanged. One would expect the same from "impotent nephrons" (1). Extractions of PAH, however, remained relatively constant in most cases.

It is also conceivable that some of the substances entering the kidney leave it via lymphatic vessels and by-pass the renal vein either after being reabsorbed, or after interstitial diffusion. Unfortunately, there is at present no innocuous way to demonstrate such a mechanism in man.

The first type of shunt should be easily demonstrable and would probably be the most important in physiopathological conditions of the kidney. There is some evidence that such shunts exist, at least in animals. Trueta claims to have seen "red blood" in the renal veins of rabbits (9). We have observed it in dogs only during trauma to the kidney at operation. Unexplained low PAH or diodrast extractions have been observed both in the dog and in man $(12,19,20)$. The existance of shunts has been postulated in order to explain "reflex anuria" (21), and the "crush syndrome" (9). These observations have been made usually under experimental, operative or severe pathological conditions. The importance of anastomoses would be greater if they were concerned with ischemia of certain parts of the kidney, and if relatively mild stimuli (nervousness, autonomic instability, emotional factors, pain) would be able to shift the cortical circulation to a medullary one. For that reason, epinephrine was used in our experiments. Histamine was employed as well, because a renal action somewhat similar to that of epinephrine has been demonstrated (22).

functional to any great extent, at the expense of the cortex, one might expect a considerable depression of the extraction of both mannitol and PAH. 
When renal arterio-venous oxygen differences were measured in the dog, Trueta's findings appeared to be confirmed, i.e., the oxygen content in renal venous blood increased after the intravenous injection of epinephrine. However, when hematocrit, oxygen capacity and plasma proteins were also determined, (Table I), it appeared that this increase was simulated by a marked hemoconcentration (according to oxygen capacity and hematocrit), of as much as 22.2 per cent in the renal blood, and of only 4.4 per cent in the peripheral blood in one case (Figure 3 ). The increase in plasma proteins was not as striking. When arterio-venous differences were corrected to a constant oxygen capacity, epinephrine appeared to cause an increase (from 2.2 to 4.7 volumes per cent). We observed the same increase in experiments in which mild reactions to epinephrine were elicited and negligible hemoconcentration occurred (Nos. 102, 105, and 112).
However, only renal venous and femoral arterial blood were compared. According to Dole, et al. (23) unexplained differences in the oxygen capacity of renal and peripheral blood can be observed in the dog. Therefore, in later experiments samples were drawn simultaneously from the renal vein, renal artery, and sometimes from the femoral artery. At variance with the assumption of Dole, it was found that there was a consistent difference between venous and arterial renal hematocrits (and oxygen capacities), the former being more concentrated. This difference was increased by epinephrine and decreased by caffeine (Nos. 116 and 117). This hemoconcentration cannot be entirely explained by the amount of excreted urine. With a diuresis of $0.5 \mathrm{cc}$. per minute, the expected hemoconcentration would be only 0.5 per cent. Even if epinephrine reduces renal blood flow more than urine flow, hemoconcentration greater than 2 or 3 per cent is not likely. Therefore, some loss

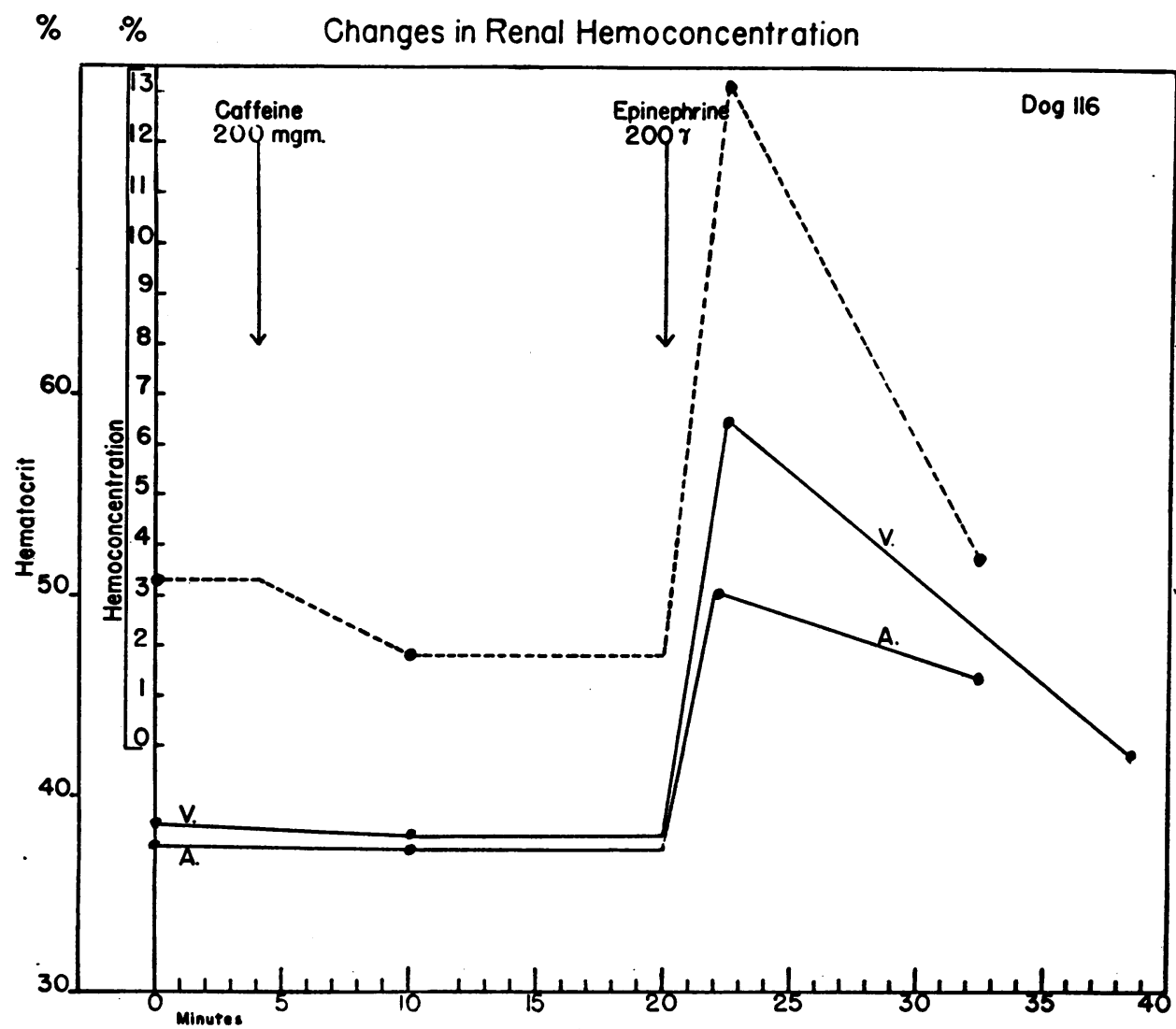

Fig. 3. Changes in the Hematocrit (- - ) and Hemoconcentration (-- ) in One Dog following the Intravenous Injection of Caffeine and Epinephrine

$\mathrm{V}$ refers to that in the renal venous, $A$ to that in the renal arterial blood. Note the rise immediately after epinephrine was given. 
of fluid from the kidney occurs which is not accounted for except by passage through lymphatic or capsular vessels $(7)^{6}$ or by what is unlikely and was not seen, a marked swelling of the kidney itself.

The increase in the hematocrit difference after epinephrine indicates that this removal of fluid is not dependent on the blood flow but rather on the filtration rate. This suggests that lymphatic vessels might be concerned in the tubular reabsorption of fluid. The inverse action of caffeine can best be

- According to Kaplan, Friedman and Kruger (24) renal lymph in the dog is derived from both renal blood plasma and tubular reabsorbed fluid. These authors do not believe that the flow of lymph is very great. Technical difficulties, however, in determining the rate of lymph flow would, in our opinion, leave this question still open. explained by decreased tubular absorption and the increased renal blood flow which it produces in the narcotized dog under operative conditions. The fact that the difference in serum proteins is less marked than the difference in hematocrit or oxygen capacity is not surprising, since the protein content of renal lymph is about one-half that of the plasma (25).

In human subjects the arterio-venous oxygen difference was increased except in two (W. G. and F. W.). Unfortunately, hematocrits were not determined, but total proteins measured in stored plasma samples were significantly higher in renal venous blood after epinephrine was given. The same mechanism as in the dog experiments can be tentatively applied to this observation. It should be kept in mind, however, that in human beings

TABLE III

Changes in arterio-renal venous differences in patients after injection of vasoactive drugs

\begin{tabular}{|c|c|c|c|c|c|c|c|c|c|c|}
\hline Subject & $\begin{array}{l}\text { Drug } \\
\text { and } \\
\text { dose }\end{array}$ & $\begin{array}{c}\text { Time } \\
\text { after } \\
\text { injection }\end{array}$ & $\begin{array}{c}\text { Oxygen } \\
\text { content } \\
\mathrm{FA}-\mathrm{RV}\end{array}$ & $\begin{array}{l}\text { PAH } \\
\text { content } \\
P-R V\end{array}$ & $\begin{array}{c}\text { PAH } \\
\text { content } \\
\text { Extrac- } \\
\text { tiont }\end{array}$ & $\begin{array}{c}\text { Mannitol } \\
\text { content } \\
\mathrm{P}-\mathrm{RV}\end{array}$ & $\begin{array}{c}\text { Mannitol } \\
\text { content } \\
\text { Extrac- } \\
\text { tionf }\end{array}$ & $\begin{array}{l}\text { Plasma } \\
\text { proteins } \\
\text { RV }\end{array}$ & $\begin{array}{l}\text { Hemato- } \\
\text { crit } \\
R V-F A\end{array}$ & Diagnosis \\
\hline${ }^{*}$ W. G. $\sigma^{x}$ & $\begin{array}{l}m g m . \\
0.5 \mathrm{E}\end{array}$ & $\begin{array}{c}\text { min. } \\
0 \\
10 \\
33\end{array}$ & $\begin{array}{l}\text { vol. \% } \\
4.7 \\
1.8 \\
0.7\end{array}$ & $\begin{array}{c}m g m . \% \\
1.29 \\
0.80 \\
0.71\end{array}$ & $\begin{array}{c}\% \\
86.0 \\
83.3 \\
84.5\end{array}$ & $m g m . \%$ & $\%$ & $\begin{array}{c}\text { gm. \% } \\
5.6 \\
6.2\end{array}$ & $\%$ & $\begin{array}{l}\text { Diabetes, arterio- } \\
\text { sclerosis }\end{array}$ \\
\hline *P. C. $\sigma^{7}$ & $0.5 \mathrm{E}$ & $\begin{array}{c}0 \\
5-8 \\
19-27\end{array}$ & $\begin{array}{l}1.5 \\
3.1 \\
1.6\end{array}$ & $\begin{array}{l}3.36 \\
2.46 \\
1.22\end{array}$ & $\begin{array}{l}91.0 \\
90.5 \\
84.5\end{array}$ & $\begin{array}{l}27 \\
37 \\
27\end{array}$ & $\begin{array}{l}13.5 \\
21.4 \\
18.2\end{array}$ & & & $\begin{array}{l}\text { Cong. heart dis- } \\
\text { ease, syphilis }\end{array}$ \\
\hline *F. W. $\%$ & $0.5 \mathrm{E}$ & $\begin{array}{c}0 \\
6-8 \\
16-19\end{array}$ & $\begin{array}{l}1.6 \\
0.3 \\
2.3\end{array}$ & $\begin{array}{l}6.95 \\
4.54 \\
3.16\end{array}$ & $\begin{array}{l}79.7 \\
77.7 \\
69.6\end{array}$ & $\begin{array}{l}19 \\
22 \\
11\end{array}$ & $\begin{array}{r}13.6 \\
16.9 \\
9.2\end{array}$ & $\begin{array}{l}6.0 \\
6.2\end{array}$ & & $\begin{array}{l}\text { Hypertension, } \\
\text { obesity }\end{array}$ \\
\hline W. D. $\sigma^{7}$ & $0.7 \mathrm{E}$ & $\begin{array}{c}0 \\
4-6 \\
20-21 \\
40\end{array}$ & $\begin{array}{l}2.1 \\
2.7 \\
2.8\end{array}$ & $\begin{array}{l}2.61 \\
2.62 \\
2.93 \\
2.95\end{array}$ & $\begin{array}{l}89.5 \\
90.0 \\
87.0 \\
83.7\end{array}$ & $\begin{array}{l}21.4 \\
31.1 \\
33.0 \\
17.8\end{array}$ & $\begin{array}{l}20.1 \\
30.8 \\
33.3 \\
19.1\end{array}$ & & $\begin{array}{r}-.35 \\
.65 \\
.00\end{array}$ & Hypertension \\
\hline D. B. $\%$ & $0.5 \mathrm{E}$ & $\begin{array}{r}0 \\
0 \\
6 \\
12 \\
26\end{array}$ & $\begin{array}{l}1.9 \\
1.6\end{array}$ & $\begin{array}{l}3.33 \\
3.21 \\
3.61 \\
3.66 \\
3.24\end{array}$ & $\begin{array}{l}88.8 \\
85.7 \\
87.6 \\
89.0 \\
86.4\end{array}$ & $\begin{array}{l}31 \\
27 \\
36 \\
23 \\
24.6\end{array}$ & $\begin{array}{l}26.7 \\
24.1 \\
32.5 \\
21.7 \\
24.1\end{array}$ & & $\begin{array}{l}.10 \\
.00\end{array}$ & Hypertension \\
\hline G. S. $\%$ & $0.4 \mathrm{E}$ & $\begin{array}{l}0 \\
0 \\
0 \\
5-19 \\
33 \\
41 \\
48\end{array}$ & & $\begin{array}{l}1.88 \\
1.91 \\
1.88 \\
2.21 \\
2.36 \\
2.23 \\
2.26\end{array}$ & $\begin{array}{l}44.7 \\
41.1 \\
38.5 \\
42.4 \\
44.0 \\
42.7 \\
42.5\end{array}$ & $\begin{array}{l}11 \\
10 \\
18.5 \\
14.5 \\
11.0 \\
10.5\end{array}$ & $\begin{array}{r}9.8 \\
8.9 \\
16.3 \\
13.0 \\
10.0 \\
9.7\end{array}$ & & & Hypernephroma \\
\hline V. R. ? & $0.5 \mathrm{E}$ & $\begin{array}{r}0 \\
0 \\
5 \\
10 \\
22 \\
36 \\
54\end{array}$ & & $\begin{array}{l}2.58 \\
2.48 \\
2.77 \\
2.47 \\
2.07 \\
2.53 \\
2.51\end{array}$ & $\begin{array}{l}89.0 \\
91.5 \\
92.0 \\
92.0 \\
93.0 \\
92.5 \\
93.5\end{array}$ & $\begin{array}{l}29 \\
24 \\
39 \\
34 \\
31 \\
31 \\
27.5\end{array}$ & $\begin{array}{l}22.0 \\
18.7 \\
31.3 \\
28.5 \\
27.3 \\
27.1 \\
24.4\end{array}$ & & & Hypertension \\
\hline
\end{tabular}


TABLE III-Continued

\begin{tabular}{|c|c|c|c|c|c|c|c|c|c|c|}
\hline Subject & $\begin{array}{l}\text { Drug } \\
\text { and } \\
\text { dose }\end{array}$ & $\begin{array}{c}\text { Time } \\
\text { after } \\
\text { injection }\end{array}$ & $\begin{array}{c}\text { Oxygen } \\
\text { content } \\
\text { FA-RV }\end{array}$ & $\begin{array}{c}\text { PAH } \\
\text { content } \\
\mathbf{P}-\mathbf{R V}\end{array}$ & $\begin{array}{c}\text { PAH } \\
\text { content } \\
\text { Extrac- } \\
\text { tiont }\end{array}$ & $\begin{array}{l}\text { Mannitol } \\
\text { content } \\
P-R V\end{array}$ & $\begin{array}{c}\text { Mannitol } \\
\text { content } \\
\text { Extrac- } \\
\text { tiont }\end{array}$ & $\begin{array}{l}\text { Plasma } \\
\text { proteins } \\
\text { RV }\end{array}$ & $\begin{array}{l}\text { Hemato- } \\
\text { crit } \\
\text { RV-FA }\end{array}$ & Diagnosis \\
\hline H. D. & $\begin{array}{l}m g m . \\
0.7 \mathrm{E}\end{array}$ & $\begin{array}{c}\min . \\
0 \\
0 \\
4 \\
10 \\
22 \\
40\end{array}$ & vol. \% & $\begin{array}{c}\text { mgm. \% } \\
2.88 \\
3.08 \\
3.44 \\
3.59 \\
3.59 \\
4.09\end{array}$ & $\begin{array}{c}\% \\
93.3 \\
93.6 \\
92.0 \\
90.9 \\
92.3 \\
92.4\end{array}$ & $\begin{array}{l}\text { mgm. \% } \\
11 \\
13 \\
15 \\
17\end{array}$ & $\begin{array}{c}\% \\
10.0 \\
11.5 \\
13.3 \\
14.8\end{array}$ & gm. \% & $\%$ & Peptic ulcer \\
\hline H. T. ه & $0.8 \mathrm{E}$ & $\begin{array}{l}0 \\
0 \\
3.5 \\
8 \\
24 \\
39\end{array}$ & & $\begin{array}{l}1.34 \\
1.41 \\
1.76 \\
1.79 \\
2.04 \\
2.06\end{array}$ & $\begin{array}{l}95.0 \\
94.0 \\
94.7 \\
93.2 \\
95.3 \\
94.5\end{array}$ & $\begin{array}{c}* 2.18 f \\
2.56 \\
3.07 \\
3.48 \\
3.08 \\
3.06\end{array}$ & $\begin{array}{l}16.2 \\
20.1 \\
25.9 \\
28.8 \\
27.5 \\
26.7\end{array}$ & & & Primary syphilis \\
\hline E. C. $\%$ & $0.5 \mathrm{H}$ & $\begin{array}{r}0 \\
0 \\
0 \\
3 \\
10 \\
23 \\
38\end{array}$ & & $\begin{array}{l}4.05 \\
4.02 \\
4.08 \\
4.14 \\
4.38 \\
3.81 \\
3.88\end{array}$ & $\begin{array}{l}88.7 \\
88.7 \\
87.1 \\
87.1 \\
87.8 \\
80.2 \\
81.1\end{array}$ & $\begin{array}{l}29 \\
30 \\
33 \\
29.5 \\
17.5 \\
10.0 \\
23.0\end{array}$ & $\begin{array}{r}20.8 \\
21.5 \\
23.7 \\
20.9 \\
11.8 \\
6.2 \\
14.1\end{array}$ & & & Hypertension \\
\hline F. C. & $0.4 \mathrm{H}$ & $\begin{array}{r}0 \\
0 \\
3 \\
9 \\
17 \\
31 \\
45\end{array}$ & & $\begin{array}{l}2.27 \\
2.24 \\
2.24 \\
2.36 \\
2.27 \\
2.10 \\
2.30\end{array}$ & $\begin{array}{l}94.0 \\
93.8 \\
92.7 \\
92.7 \\
91.3 \\
92.6 \\
93.0\end{array}$ & $\begin{array}{l}18.9 \\
16.2 \\
22.2 \\
17.4 \\
13.1 \\
11.9 \\
14.5\end{array}$ & $\begin{array}{l}18.9 \\
16.2 \\
22.7 \\
18.8 \\
14.4 \\
13.3 \\
16.3\end{array}$ & $\begin{array}{c}5.47 \\
(-0.28) \S\end{array}$ & & $\begin{array}{l}\text { Peptic ulcer, } \\
\text { Parkinsonism }\end{array}$ \\
\hline B. C. ब & $0.5 \mathrm{H}$ & $\begin{array}{r}0 \\
6 \\
20 \\
24 \\
42\end{array}$ & & $\begin{array}{l}2.19 \\
2.43 \\
2.19 \\
2.22 \\
2.10\end{array}$ & $\begin{array}{l}69.8 \\
74.3 \\
70.5 \\
72.5 \\
73.0\end{array}$ & $\begin{array}{l}14 \\
16 \\
15 \\
14 \\
20\end{array}$ & $\begin{array}{l}11.7 \\
13.1 \\
12.6 \\
11.9 \\
17.4\end{array}$ & & $\begin{array}{l}-.70 \\
-.40 \\
-.30\end{array}$ & Hypertension \\
\hline A. B. Oים & $0.5 \mathrm{H}$ & $\begin{array}{r}0 \\
0 \\
0 \\
5 \\
21 \\
37\end{array}$ & & $\begin{array}{l}3.97 \\
4.00 \\
3.90 \\
4.21 \\
4.29 \\
3.84\end{array}$ & $\begin{array}{l}80.7 \\
81.0 \\
81.2 \\
81.8 \\
80.2 \\
77.0\end{array}$ & $\begin{array}{l}21 \\
18 \\
23 \\
26 \\
27 \\
23.5\end{array}$ & $\begin{array}{l}15.3 \\
13.4 \\
16.9 \\
19.0 \\
19.0 \\
16.9\end{array}$ & $\begin{array}{l}5.95 \\
(0.00) \S\end{array}$ & & Hypertension \\
\hline *M. P. $\%$ & $\mathbf{P}$ & $\begin{array}{c}0 \\
0 \\
12-14 \\
22\end{array}$ & $\begin{array}{l}1.8 \\
2.25\end{array}$ & $\begin{array}{l}2.30 \\
0.59 \\
3.96 \\
2.68\end{array}$ & $\begin{array}{r}85.8 \\
100 ? \\
91.5 \\
89.9\end{array}$ & $\begin{array}{l}20 \\
16.3 \\
28.0 \\
33.0\end{array}$ & $\begin{array}{l}15.6 \\
22.5 \\
16.8 \\
21.7\end{array}$ & & .30 & Hypertension \\
\hline
\end{tabular}

Note: FA indicates sample taken from femoral artery, RV from renal vein and $P$ from either femoral artery or anticubital vein. All drugs except pentothal were given subcutaneously. $E=$ epinephrine; $H=$ histamine; $P=$ pentothal.

* In these cases one single injection of PAH and mannitol was given except for M. P. who was given two injections. In the remainder constant infusions were employed.

$\frac{\mathrm{P}-\mathrm{RV}}{\mathrm{P}}$.

$\ddagger$ Sodium thiosulfate used instead of mannitol.

$\$$ RV-FA.

femoral and renal venous blood were compared. In the dog there may be a discrepancy between femoral and renal arterial samples. At any rate, under control conditions, there were no significant differences between femoral arterial and renal venous hematocrits in man.
In the evaluation of renal arterio-venous oxygen differences one point must be emphasized. Reduction of blood flow may decrease greatly the oxygen content of the venous blood and partial shunting may partly compensate for this change. For that reason, unless opening of large shunts 
occurs, these determinations are of less value than $\mathrm{PAH}$ and mannitol extractions.

Changes in PAH extractions in dogs were not very consistent after epinephrine was given, and the results are not conclusive. In one case (No. 29) it fell to a very low value, but errors in technique cannot be excluded. Except for this single questionable case, there appeared no changes consistent with the opening of shunts. The results of human experiments are certainly less questionable, and due to the standard conditions under which the tests were performed, even slight variations can be considered significant. It may be assumed that partial shunting of the first type was produced by epinephrine in case F.W. (Table III), as both the PAH and the mannitol extractions were lower than the control values (11.4 and 33.3 per cent respectively). In cases $P$. C. and W.D., where the $\mathrm{PAH}$ extraction was reduced 7.1 and 6.7 per cent, the mannitol extraction was not affected, so that shunting might have excluded mainly the peritubular capillaries (type of shunting No. 3). Impairment of tubular excretory capacity due to anoxia, however, could account for this reduction (26).

Pentothal anesthesia was without visible effect in one case, and histamine may have opened shunts of the first type in one (E. C.) and of the third type in another (A. B.). At any rate, the greatest shunting elicited in one case where the reaction to epinephrine was severe, was not much more than one-tenth of the total renal blood flow. Moreover, this phenomenon was observed in a diseased kidney where the extraction was low at the beginning. Although four out of the five patients in whom changes occurred had hypertension, our findings do not support the hypothesis of Trueta, et al. that large shunts may open under physiological conditions and be responsible for intermittent cortical ischemia concerned in hypertensive disease. Bradley and Bradley (27) were unable to demonstrate appreciable reduction in $\mathrm{PAH}$ extraction after abdominal compression in eight normal subjects, although renal blood flow was reduced. While a persistently low PAH extraction by damaged hypertensive kidneys could be produced by permanent shunting, tubular impairment and the destruction of active parenchyma with subsequent replacement by fibrous tissue seems a more likely explanation. Shunts of that kind would not have any etiologic significance, being the result and not the cause of the renal alterations.

Although these experiments do not disprove the presence of arterio-venous by-passes in the kidney of man and of the dog, they do indicate that after doses of epinephrine or histamine large enough to cause systemic reactions, these vascular channels do not consistently appear. When they do, they are not very important. In the dog, furthermore, they were not demonstrated even after large doses of epinephrine. It is still possible that such channels may become functional following toxic doses of drugs, during severe shock, or after crushing wounds. Their significance in minor physiological alterations in homeostasis is therefore questionable.

\section{SUMMARY AND CONCLUSIONS}

1. Experiments involving determinations of $\mathrm{PAH}$, mannitol, oxygen content and hematocrit in renal venous and peripheral (or renal) arterial blood before and after injection of epinephrine, histamine or pentothal were performed in eight hypertensive and six normotensive patients, and in 15 dogs. In patients, renal venous blood was collected by catheterization of the right renal vein.

2. The maximal decrease in the extraction of $\mathrm{PAH}$ by the kidneys of patients after subcutaneous injection of epinephrine or histamine was 11.4 per cent; dog experiments were inconclusive.

3. In two human subjects, arterio-venous oxygen differences were increased by epinephrine, and in three, decreased.

4. In dogs, there was a consistent difference in the oxygen capacity, hematocrit, and plasma protein content between renal arterial and renal venous blood, the latter being more concentrated. This difference was increased by epinephrine. It is suggested that this loss of fluid from the renal blood may have occurred through renal lymphatic vessels or other vascular channels by-passing the renal vein.

5. From these experiments it can be concluded that large intermittent renal shunts can not be elicited in man by physiological doses, or in dogs by larger doses, of epinephrine. Even in subjects with essential hypertension, histamine or epinephrine produced relatively small and inconsistent changes which could be ascribed to the presence of shunts. 


\section{ACKNOWLEDGMENTS}

Determinations of para-amino hippurate and mannitol were made under the supervision of Dr. Palmer $\mathrm{H}$. Futcher, whose help is appreciated. The technical assistance of Miss Ellabeth Houghton, Mrs. D. Heady, and Miss Ruby M. Brooks, R.N., is gratefully acknowledged.

\section{BIBLIOGRAPHY}

1. Smith, H. W., Lectures on the Kidney. Univ. of Kansas, Lawrence, Kans., 1943.

2. Shonyo, E. S., and Mann, F. C., Experimental investigation of renal circulation. Arch. Path., 1944, $38,287$.

3. Spanner, R., Ueber Gefässkurzchlüsse in der Niere. Verh. Anat. Ges., 1938, 45, 81.

4. Huber, G. C., The arteriolae rectae of the mammalian kidney. Am. J. Anat., 1907, 6, 391.

5. Clara, M., Anatomie und Biologie des Blutkreislaufes in der Niere. Arch. f. Kreislaufforsch, 1938, 3, 42.

6. Mollendorff, W. v., Der Exkretionsapparat; in Handbuch der mikroskopischen Anatomie des Menschen, VII, 1, Springer, Berlin, 1930.

7. Schmidt, C. F., and Hayman, J. M., A note upon lymph formation in the dog's kidney and effect of certain diuretics upon it. Am. J. Physiol., 1929, 91, 157.

8. Kaiserling, H., and Soostmeyer, T. H., Die Bedeutung des Nierenlymphgefässystems für die Nierenfunktion. Wiener Klin. Wschr., 1939, 52, 1113.

9. Trueta, J., Barclay, A. E., Daniel, P. M., Franklin, K. J., and Prichard, M. M. L., Studies of the Renal Circulation. C. C. Thomas, Springfield, III., 1947.

10. Fuchs, Felix, and Popper, H., Blut- und Saftströmung in der Niere (Zur klinischen Bedeutung des Niereninterstitiums). Ergebn. d. inn. Med. u. Kinderh., 1938, 54, 1.

11. Cournand, A., and Ranges, H. A., Catheterization of the right auricle in man. Proc. Soc. Exper. Biol. \& Med., 1941, 46, 462.

12. Warren, J. V., Brannon, E. S., and Merrill, A. J., A method of obtairing renal venous blood in unanaesthetized persons, with observations on extraction of oxygen and sodium para-aminohippurate. Science, 1944, 100, 108.
13. Goldring, W., and Chasis, H., Hypertension and Hypertensive Disease. The Commonwealth Fund, New York, 1944.

14. Futcher, P. H., and Houghton, E., Deviations in the analysis for mannitol introduced by yeasting. In preparation.

15. Peters, J. P., and Van Slyke, D. D., Quantitive Clinical Chemistry; II, Methods. Williams and Wilkins, Baltimore, 1943.

16. Reubi, F. C., The renal extraction of mannitol and PAH compared to their excretion in normotensive and hypertensive subjects. J. Clin. Invest., 1948, 27, 553.

17. Reubi, F. C., Schroeder, H. A., Futcher, P. H., and Reubi, C., A discrepancy between the renal extraction and the urinary excretion of various substances (Para-amino hippurate, mannitol, creatinine, thiosulfate) in man. In preparation.

18. Heggie, J. F., Circulation in the kidney. Lancet, 1946, 2, 436 .

19. White, H. L., Observations on the behavior of diodrast in the dog. Am. J. Physiol., 1940, 130, 454.

20. Corcoran, A. C., Smith, H. W., and Page, I. H., The removal of diodrast from blood by the dog's explanted kidney. Am. J. Physiol., 1941, 134, 333.

21. Springorum, P. W., Zur Frage der funktionellen Bedeutung der arteriovenosen Anastomosen für die Niere. Klin. Wchnschr., 1939, 18, 811.

22. Reubi, F. C., and Futcher, P. H., The effects of histamine upon the renal circulation. In press.

23. Dole, V. P., Emerson, K., Phillips, R. A., Hamilton, P., and Van Slyke, D. D., The renal extraction of oxygen in experimental shock. Am. J. Physiol., 1946, 145, 337.

24. Kaplan, A., Friedman, M., and Kruger, H. E., Observations concerning the origin of renal lymph. Am. J. Physiol., 1943, 138, 553.

25. Drinker, C. K., and Field, M. E., Lymphatics, Lymph and Tissue Fluid. Williams and Wilkins, Baltimore, 1933.

26. Selkurt, E. E., Comparison of renal clearances with direct renal blood flow under control conditions and following renal ischemia. Am. J. Physiol., 1946, 145, 376.

27. Bradley, S. E., and Bradley, G. P., The effect of intra-abdominal pressure on the renal function in man. J. Clin. Invest., 1947, 26, 1010. 